\title{
The KM Times They Are A-Changin'
}

\section{Meliha Handzic ${ }^{1}$}

\begin{abstract}
This paper traces the changes in the development of the field of knowledge management (KM) over time, through a review of the representative literature and the author's own research. The paper starts by going back to the origins of KM and reflects on three significant evolutionary stages termed fragmentation, integration and fusion. Following these reflections on the KM past, the paper speculates on the possible KM future. It identifies three emerging trends named extension, specialization and reconceptualization that point to several possible KM futures. The first two involve decentralisation and regeneration of prior KM interpretations, while the third trend signals a revolutionary next KM generation. Irrespective of the direction it may take, the evidence presented in this paper suggests that KM has a future, although it may not be without challenges.
\end{abstract}

Keywords: knowledge management (KM); KM development; KM past; KM future.

\section{INTRODUCTION}

Knowledge management (KM) is a young discipline, only thirty or so years in the making. It is therefore not surprising that there is a lack of clarity and agreement on what KM means, what its objectives are and what value to individuals and collectives their accomplishments can bring.

On the bright side, it appears that there is a healthy research community interest in KM aimed at providing answers to the above questions. This is reflected in a substantial number of recent articles devoted to the analysis of the field using scientometric methods (Serenko \& Dumay, 2015a; 2015b), as well as more traditional (Handzic 2015; 2016) or structured (Massaro et al., 2015; 2016a) literature reviews.

Such findings contradict some recent reports of the pessimistic views of KM as the management fad facing inevitable decline (Garlatti \& Massaro, 2015). Furthermore, they reinforce other evidence of the ongoing interest in

1 Meliha Handzic, Professor, International Burch University, Campus Ilidza, Francuske revolucije bb, 71000 Sarajevo, Bosnia and Herzegovina, e-mail: meliha.handzic@ibu.edu.ba.

NOTE: The article's title is inspired by Bob Dylan's 1964 song: The Times They Are A-Changin' 
the field, shown by numerous existing associations, conferences, publishing outlets and academic programs. Indeed, Serrat (2017) asked, "If knowledge is the strategic resource of the 21st century, how can its management be thought redundant?"

The good news is that some significant advances have been made over the past decades of KM history. These advances have been well documented in the recent literature (Bolisani \& Handzic, 2015). However, despite the many advances made, it seems that people are still struggling with the great variety and vagueness of different views on what $\mathrm{KM}$ is and where it will go. According to Spender (2015), KM is not yet a coherent academic field with an established body of ideas, methods, and target phenomena. Therefore, those who wish to map the field of KM are faced with considerable challenges.

Predicting the future can be a particularly risky business as testified by many famous historic blunders (McQuary \& Hester, 2011). Yet, to continue the KM journey, it is important to know "which way we ought to go from here" if we want to get to the full recognition of $\mathrm{KM}$ as a discipline and ensure its survival and advancement (Hasan \& Handzic, 2003).

Recognising the need to link up-to-date KM research with future challenges, the main purpose of this paper is to trace the development of KM over time through a review of the representative literature and the author's own research. It is hoped that such a brief will help provide some answers to the lingering questions of KM meaning and value, as well as offering a peek into its future. The section on the KM past builds on the author's earlier work (Handzic, 2016), while the section on KM future speculates on KM in the future despite risking to be wrong.

\section{METHODOLOGICAL CONSIDERATIONS}

A traditional literature review was adopted as a research methodology for this study, as its goal was to provide an overview of the research findings on the topic of KM development over time. Conducting a literature review is considered particularly important when a field of inquiry (in this case KM) changes. Generally, the method involves authors reading relevant studies and organizing emerging themes in order to develop a comprehensive understanding of the main findings. In this way a valid synthesis of the research literature can be developed and additional interesting insights can be generated. A critical summary of the literature reviewed for this study is organized into two main sections around KM trends identified in its past and predicted for its future. 


\section{LITERATURE BACKGROUND AND CONCEPTS}

\section{KM past and origins of KM}

For understanding the historical development of the field of $\mathrm{KM}$, it is necessary to start with the modern organizational theories, especially RBV (the resource-based view of the firm) and KBV (the knowledge-based view of the firm). The major contribution of RBV is that it refocused strategic thinking about the firm from external competitive forces to internal organizational resources as its key success factors. The special contribution of KBV is in recognising knowledge as the most important strategic resource of a firm. This recognition led to another major concern over how to deal with the required new and available existing knowledge to ensure successful performance and achieve competitive advantage. The initial response was offered by the concept of a learning organization. The argument put forward was that each firm had to learn and transform constantly in order to remain competitive in its business environment. Building on this initial idea, knowledge management (KM) appeared as the latest response of management science and practice to the recognised need for development and utilization of knowledge assets for organizational survival or advancement in the $21^{\text {st }}$ century. In order to better understand what KM is, the following sections chronicle the evolutionary development of the field since its inception.

It is hard to pin-point an exact date when the term knowledge management (KM) entered the lexicon. Usually, the coining of the term and its first use is attributed to Karl Wiig, who introduced the concept at an ILO conference in Zurich in 1986 (Lelic, 2002). Karl-Erik Sveiby also used the term in his 1986 book "Knowledge Companies" published in Sweden (Schlussel, 2009). Sometimes, the KM beginning is linked to the publication of another book by Sveiby entitled "Managing Knowhow" back in 1987 (Favero, 2016).

While Wiig and Sveiby are often described as the founding fathers of KM, Spender (2015) warns that knowledge management is not a new concept, as people were always keeping records and watching costs. However, its rapid development over the past 30 years may be attributed to three megatrends: globalization, ubiquitous technological development and knowledge-centric economy.

A number of management theorists have contributed to the evolution of knowledge management. Among notable KM pioneers are: Peter Drucker and Thomas A. Stewart who stressed the importance of knowledge as a source of competitive advantage; Peter Senge and Chris Argiyris who introduced the concept of a learning organization; as well as Robert M. Grant and John C. Spender for their work on the knowledge-based theory of the firm. 
However, it was in 1995 that KM truly captured management attention with the publication of the widely read work "The Knowledge-Creating Company: How Japanese Companies Create the Dynamics of Innovation" by Ikujiro Nonaka and Hirotaka Takeuchi. This book is considered as one of the most important contributions to the burgeoning field of knowledge management in the 1990s. Another important book that established the enduring vocabulary and concepts in KM appeared soon after in 1998. It was co-authored by Thomas H. Davenport and Laurence Prusak under the title "Working Knowledge: How organizations manage what they know". The coauthors of these two books were voted the most influential persons in KM (Edwards et al., 2003).

Since 2000, the term knowledge management has been in widespread use, as attested to in the titles of many new books, as well as in numerous articles in business publications. Research from other disciplines (e.g. library, computer, cognitive and organizational sciences) has also embraced the field as a means of solving the problems of today's economy and society. Still, this "science" appears to be struggling with constructing its road of validation, still looking for its true destination. Therefore, the following sections will try to identify where it stands at the moment, and where it can go from here.

\section{Three stages of KM development}

There have been a number of significant periods in the evolutionary development of KM. One of the most popular accounts of change in KM over time identifies three KM generations (Snowden, 2002). The focus of the first generation was on explicit knowledge and technology. In the second generation, the emphasis was on human and cultural factors, while contextual contingencies took a central place in the third generation. Another historical account distinguishes among three KM eras that involve: leveraging explicit knowledge, leveraging experiential knowledge and leveraging collective knowledge. This account views changes over the three eras in terms of expanding understanding and the creation of new sets of KM practices (Dixon, 2010). The third account is more detailed and traces KM evolution by using the seven ages of human analogy: information management-IM (infancy), KM emergence (childhood), bandwagon (adolescence), consolidation (adulthood), re-evaluation (middle-age), social KM (old age), analytics (veryold age). This model assumes that growing and maturity brings a greater understanding of KM and its value to organizations (Skyrme, 2013). There are also some mentions in the literature of the fourth and fifth KM generations (Cummings et al., 2013). 
A different way of analysing KM change was offered by Handzic (2016). It identified two significant moments as a basis for the analysis. First, it is a widespread recognition that KM is not solely about technology, or solely about people, but has five interlocking aspects, covering content, process, people, strategy, and technology. Second, it is a growing belief that blending $\mathrm{KM}$ with other disciplines can significantly boost productivity and effectiveness outcomes. The following sections briefly present descriptions of each of the three historical KM stages termed fragmentation, integration and fusion. These stages are depicted graphically in Figure 1. The figure shows three fragmented KM schools (technocratic, behavioral, and economic), integrated KM components (context, driver, enabler, process, stock, and outcome) and examples of KM fused into other disciplines (e.g. e-learning, CRM, health informatics, and digital humanities).

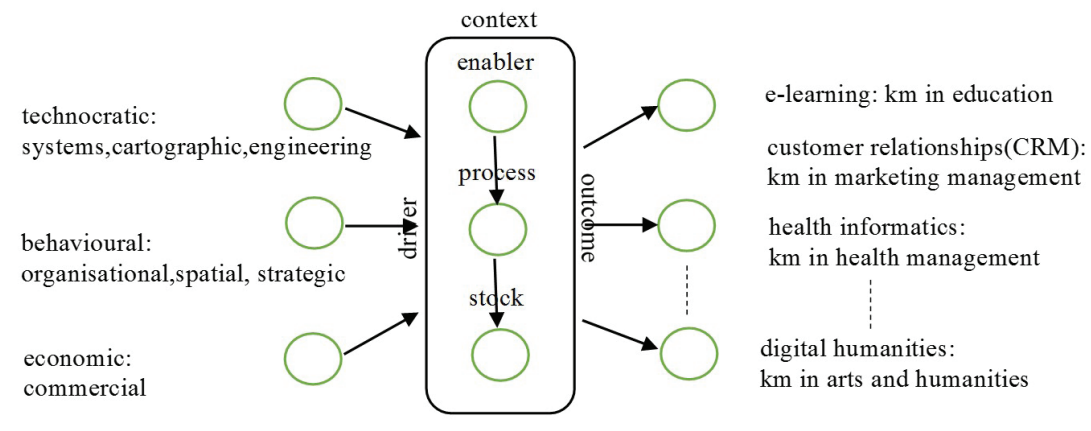

FRAGMENTATION

INTEGRATION

FUSION

Figure 1. Three stages of KM development

\section{Fragmentation}

Earl's (2001) taxonomy of major KM schools of thoughts is used here as a frame for discussing the fragmented nature of the field in the 1990s. The schools are divided into three general categories: technocratic, economic and behavioral.

The technocratic school of KM consists of the systems, cartographic and engineering schools. Similar to the first generation KM, it views knowledge as an object and places emphasis on the role of information and communication technologies in KM. The systems school focuses on formalised knowledge bases that make explicit knowledge of human experts available for use by 
non-experts. The cartographic school focuses on knowledge directories or yellow pages that allow others to locate experts' tacit knowledge that they need. The engineering school focuses on processes and knowledge flows. From the engineering school perspective, KM systems are used to document knowledge processes and store best practices in shared databases, warehouses and document management systems. Hahn and Subramani (2000) identified a number of issues and challenges related to the utilization of information and communication technologies for KM. These include the need to balance knowledge exploitation and exploration, overload and useful content, additional workload and accurate content. There is also a need for flexibility, evolutionary development and user acceptance of knowledge systems.

The behavioral school of $\mathrm{KM}$ is similar to the second generation KM. It consists of the organizational, spatial and strategic schools. The focus of the organizational school is on the sharing and pooling of knowledge by networked employees. The spatial school focuses on creating physical spaces for greater facilitation of knowledge exchange. Nonaka and Konno's (1998) concept of "ba" extends the notion of place to four types: originating, interacting, cyber and exercising. They promote four knowledge processes: socialisation, externalization, combination and internalization which enable knowledge creation. The strategic school emphasises the importance of KM as a firm's strategy. In general, the behavioral group of models addresses issues of complexity, organizational culture and learning, change and risk management, and the support of communities of practice.

The economic school of thought of KM focuses on the idea of knowledge as a competitive resource. Sveiby's (1997) model of Intellectual Capital (IC) is one of the first and best known representatives in this category. This model incorporates human, structural and relational capital as the key knowledge assets from which organizations extract value. From the IC perspective, KM aims to create value from knowledge assets by maximising the interrelationship between different types of organizations' intellectual capital. In contrast, Earl's (2001) commercial category is more concerned with protecting and exploiting a firm's knowledge or intellectual assets to produce revenue. It emphasises the importance of patents and copyrights as means to protect these assets.

\section{Integration}

The variation between different schools of thought on knowledge management is an indication of the many problems the concept poses. This led to a number of projects worldwide that worked on integrated models of 
KM during the 2000s. The aim was to provide KM researchers with a holistic view, common ground and consistent terminology, and units of analysis across a variety of settings. There was also a need to develop frameworks that could help practitioners to understand the sorts of KM initiatives or investments that are possible and to identify those that make sense in their context.

According to Hasan and Handzic (2003), all integrated frameworks consider $\mathrm{KM}$ as a complex and multidimensional concept; synthesise the object and human perspectives of knowledge; view KM as both a social and technological concept; and recognise the evolutionary and contextual nature of $\mathrm{KM}$. In this paper, I use the knowledge context-driver-enablerprocess-stock-outcome model adapted from Handzic et al. (2008) as a basis for discussing the fundamental concepts of $\mathrm{KM}$ in a holistic manner. The integrated KM model essentially provides a link between different fragmented $\mathrm{KM}$ approaches and generations. The main contribution of the model is that it helps organise various factors in a more meaningful way. While the model was conceived with a view of organizations, it may be applicable to different individual and collective levels.

The model core views KM as configurations of an organization's sociotechnical knowledge enablers, knowledge processes and knowledge stocks. Supported by Nonaka and Konno's (1998) concept of ba, the model brings together the technology, maps, spatial and networks categories of Earl's (2001) technocratic and behavioral schools of KM. It emphasises the importance of both social and technical factors in enabling and facilitating knowledge processes. Organizational environment with proactive leadership and open culture is assumed to help create a knowledge-conducive climate and technological infrastructure to facilitate knowledge processes.

The knowledge process component of the model covers various processes through which knowledge is moved (e.g. transfer person-to-person, personto-document) and modified (e.g. creative idea generation, mining of hidden patterns in captured data). The underlying assumption is that the better the processes of knowledge generation, sharing, capture and discovery, the greater the likelihood that the knowledge needed will be available leading to more effective and innovative organizational performance. The knowledge stock component draws from Earl's (2001) economic, and Sveiby's (1997) intellectual capital perspectives, where knowledge is seen as a valuable organizational asset. More importantly, it brings together different perspectives of knowledge (human and object, explicit and tacit, know-what and know-how) by proposing a multidimensional view.

Furthermore, the integrated model takes a contingent theoretical approach to KM which argues that no one solution is best under all circumstances. It gives contextual contingencies (e.g. task-, environment- 
and person-related) an important place in selecting the right $\mathrm{KM}$ choice that best fits a particular set of circumstances. A number of researchers provide considerable theoretical and empirical support for the view (e.g., Hansen et al., 1999; Becerra-Fernandez \& Sabherwal, 2001; Snowden, 2002; BecerraFernandez et al., 2004).

The model also recognises explicitly that KM is driven by forces from its surrounding external environment. Australian KM standard (AS5037, 2003) describes KM drivers as strategic levers through which an organization delivers its desired outcomes. It identifies operational excellence, stakeholder intimacy, service delivery, growth, sustainable profitability and risk mitigation among core strategic drivers found across for- and non-profit sectors. Earl's (2001) strategic category provides further reinforcement of the view of knowledge as a competitive weapon and points to the importance of KM consciousness in a firm's business strategy.

Finally, the integrated model includes a KM outcome component that allows assessing of the impacts of KM on organizational performance. Australian KM standard (AS5037, 2003) identifies two principal benefits of undertaking KM: improving productivity and organizational efficiency, and promoting innovation. Earl's (2001) economic school of KM suggests that when aligned with business strategy, KM may generate revenue and profit through the use of knowledge to create innovative and improved products and services. It may also generate a sustainable competitive advantage by effective use of its accumulated intangible assets to develop and exploit other tangible resources better than the competitors.

While it may be hard to identify all the immediate benefits from a KM initiative, organizations need to get some feedback on the degree to which KM fulfils their articulated drivers. Both knowledge and outcome measurements are needed in continuous knowledge audits and for eventual adjustment of KM strategies over time.

\section{Fusion}

Most recently, scholars have started to call for convergence between KM and other disciplines in order to broaden research interests and opportunities in academia and enhance their value to practice. Some notable attempts include conceptual models connecting KM and BPM (business process management), KM and communication management; KM and IC (intellectual capital); and KM and PM (project management).

The combined KM and BPM solution is based on the connection between process model and corporate knowledge base (Ternai et al., 2014). In particular, the process structure is used for building up the knowledge 
structure (ontology) of a certain domain. By using the ontology and combining it with the process model, knowledge management and business process management are connected in a dynamic, systematic and controlled manner. In another research with the intersection and complementation of different disciplines, the cooperation model of an organization's dynamic communication is built for a research organization based on the definitions and characteristics of knowledge management and communication management (Wu et al., 2007). Among those arguing the connections between KM as a dynamic and IC as a static perspective on knowledge, Kianto et al. (2014) proposed several alternative models on how these knowledge-based issues affect organizational performance. In some proposed options, KM practices moderate or mediate the effect of IC assets on performance. In other options, IC assets moderate or mediate the effect of KM practices on performance.

Advocates of KM's integration with PM claim that it is necessary to enable the people involved in the project to take individual contributions to the project's objectives and align them with the organization's strategic objectives (Levin, 2010). So far, several attempts have been made to combine aspects of KM and PM in order to improve project success (Cope et al., 2006; Lierni \& Ribiere, 2008; Owen, 2008; Ismail et al., 2009; Gudi \& BecerraFernandez, 2006; Yeong \& Lim, 2010). Most recently, Handzic and Durmic (2015) proposed a new conceptual model which combines factors from three fields in a way that can increase the rate of project success in organizations. This model includes a set of interrelated components derived from KM, IC and PM frameworks. From KM, the proposed model adopted contextual contingencies and drivers of $\mathrm{KM}$, as well as $\mathrm{KM}$ practices comprising sociotechnical knowledge enablers and processes. From PM, the model adopted people (project team and customer) and process (project planning, execution, verification) elements as critical IC dimensions, and project success as PM, as well as $\mathrm{KM}$ as an outcome component. With respect to relationships, the proposed model recognises that various motivational forces and contextual contingencies drive and influence the choice and application of KM practices in PM and thus indirectly impact project success.

While all of these merger models point to the importance of KM consciousness, Cervone (2016) warns that in some cultures, KM has diffused to the point where it is no longer considered a separate thing, but a natural part of how people organise work. Consequently, it becomes invisible not only in the process, but also in the name. There are many examples of this trend. Thus, e-learning represents a clear case of KM fusion in education. Customer relationship management (CRM) is a specific application of KM in marketing. Health informatics and biomedical informatics are the products of the merger of knowledge and health management. Furthermore, digital disciplines such 
as digital arts and humanities sit at the crossroads of traditional, digital and knowledge sciences. For example, at Stanford (http://shc.stanford.edu/ digital-humanities), digital humanities projects focus on the preservation of archival material for posterity through digitization and mapping the exchange and transmission of ideas in history. They have implemented sophisticated KM tools such as 3-D mapping, algorithmic literary analysis and advanced visualisation techniques. This enables researchers to experiment with source materials, as well as share knowledge and build a community.

While the fusion stage may lead to the complete disappearance of $\mathrm{KM}$ as a distinct field, this would indicate the true success of $\mathrm{KM}$ according to some scholars (Kay, 2003) However, here lays the danger that organizations may forget what they knew about KM and fail to manage their knowledge for the benefit of their business. So, the position advocated by this paper is that the possible "next KM generation" should make sure that KM remains relevant and rigorous to guarantee the field to proceed.

\section{KM future}

The above historical chronicle of the field shows that KM has made some significant advances since its inception. However, after three decades of high visibility, the field has recently come under critical scrutiny questioning its future. A recent controversial remark by Davenport (2015) that KM is "gasping for breath" has caused concern in some parts of the KM community. Reacting to this statement, O'Leary (2016) reviewed several emerging KM concepts; investigated empirical evidence of KM trends using Google Scholar and Google Trends; traced Gartner's history of KM from a hype cycle perspective; reviewed arguments behind "KM is dead" proclamations; analysed the concern about KM value; and finally concluded that "it does not appear to be dead or dying", but "it does appear that knowledge management is continuing to evolve". Therefore, the time seems right to take a closer look at what the future might hold.

\section{Moving KM forward}

The future of knowledge management has been recognised as an area of interest to both academics and practitioners since its inception (Girard \& Ribiere, 2016). However, the majority of scholarly articles that looked to the future of KM were published back in the 1990s, when KM gained momentum. These pioneering works charted the KM course for many researchers over the past three decades. Unfortunately, only a few scholars addressed the issue in recent years in order to help chart the KM course in the next decade and beyond. 
These proponents of the "next generation" pointed to the "blue ocean" of opportunities for KM regeneration or revolution. Thus, Bedford and Lewis (2015) suggested the following possible ways ahead: chances for testing new ideas and practices presented by the emerging trans-disciplinary and/ or inter-disciplinary fields of study; organizations incentivised by the growing knowledge economy and society to learn and experiment with KM ideas; changing historical nature of disciplines evolution through common practices rather than around core theories. Also adopting the next KM generation concept, Schmitt (2015) proposed advancing KM towards individualization and innovationalization. He also outlined his own personal KM system in the making.

From an explorative study of KM experts' views Heisig (2015) recommended: revisiting some fundamentals such as the concepts of knowledge and KM process; exploration of ecological and biological models of the KM environment; examination of the KM relationships with other disciplines such as organizational studies, innovation and human resources management; looking beyond KM technology to human and social factors and the related root disciplines of psychology and sociology; and consideration of the macro-economic and societal outcomes of KM. Based on yet another recent study of KM experts' views Girard and Ribiere (2016) mapped KM's future using Earl's (2001) taxonomy. The aim was to discover areas that offer interesting KM research opportunities for the future. The engineering, cartographic and systems schools emerged as the top three schools. Thus, this study predicted technocratic approaches as the most likely areas of KM research and practice in the near future.

However, argued Handzic (2016), in the long term, the challenge is to develop novel models that will incorporate enough of the contextual complexities to be effective, while remaining simple enough that people who are not KM experts can use them. A way ahead may be what Skyrme (2013) calls reincarnation, with KM taking on a new lease of life and being reinvigorated.

\section{Three emerging KM trends}

In order to make sense of various views and predictions for the KM future found in the recent literature, the author categorised them into three emerging trends termed extension, specialization and reconceptualization. They differ in the nature and extent of change they bring to the field through the ongoing broadening, deepening, adapting, repurposing or innovating activities of the KM concept. Thus, the first two represent evolutionary developments within the existing theoretical frameworks, while the third one points to the shifting paradigm of knowledge and science that brings radical 
change. The following sections take a closer look at each of the three emerging trends shown in Figure 2. The figure shows three major KM specializations (big data, social KM, innovation management), examples of extended range of KM components (wider enablers and processes, deeper stocks) and three novel conceptual developments (data science, connectivism/collectivism, human/nature-based KM).

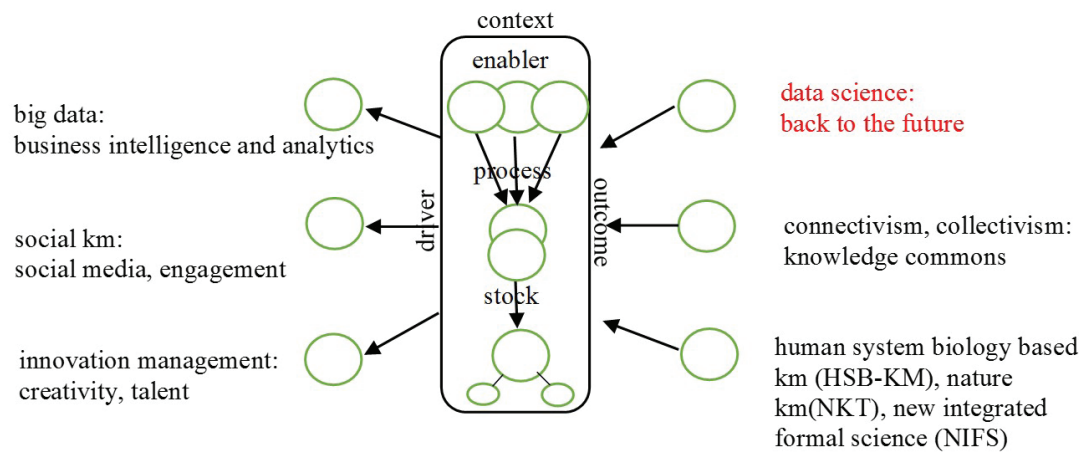

SPECIALISATION

EXTENSION

RECONCEPTUALISATION

Figure 2. Three emerging KM trends

\section{Extension}

The extension trend can be best described in terms of a widening and deepening of the existing integrated model of KM. This widening is especially visible in the technology arena with new technologies emerging daily. The Cloud, open linked data, Al applications, and the Internet of Things are only some of the latest developments to better enable and facilitate knowledge processes. These sophisticated KM tools promise to deliver knowledge that will improve its application and impact; connect people in the best way to transfer knowledge; connect knowledge and the power of knowledge discovery; and accelerate the expertise development that is crucial as the baby boomers retire (McQuary \& Hester, 2011).

The widening tendencies are not confined to the technology sphere alone. The ever-growing volumes of explicit knowledge deposited in linked repositories provide opportunities that affect the logistics of knowledge seekers and suppliers (Schmitt, 2015). The curation of the world's intelligence is one important newly introduced KM activity that ensures its reliability and retrievability for future research and reuse purposes. 
With respect to $\mathrm{KM}$ applications, they are spreading from primary to tertiary sectors, from commercial to government to non-profit contexts, from personal to global levels. The variety of applied KM practices is well documented by Ark Group, a leading provider of business information in Australia (http://www.arkgroupaustralia.com.au/). It is interesting to note that the supporting voices urging for more personal KM applications that give power and autonomy to individuals and self-organised groups are growing in number (Schmitt, 2015). There are also other voices that promote KM as a means for the predominantly social change (Tuomi, 2002).

The deepening of KM is clearly manifested in the deconstruction of the concept of intellectual capital (IC). The original Sveiby (1997) model of IC incorporates human, relational and structural capital as the key knowledge assets from which organizations extract value. More recently, these three concepts themselves have been recognised as being complex and multidimensional. Specifically, Molodchik et al. (2014) decomposed human capital (HC) into the abilities of management and human resource capabilities; structural capital (SC) into innovation and internal process capabilities; and finally, relational capital (RC) into networking capabilities and customer loyalty.

In summary, the extension trend retains the holistic approach to KM while harnessing the power of new technologies and deeper insights gained into the field for the benefit of all segments of the knowledge society and economy.

\section{Specialization}

The specialization trend may be viewed in terms of the adaptation and repurposing of $\mathrm{KM}$. In the first instance, specialization may resemble fragmentation, as its focus is often on a part of KM rather than on the whole. However, the difference between the two stages is in the present awareness of the whole-part relationship compared to the earlier partial views of the "proverbial KM elephant". Some scholars also argue that KM requires the development of specialized studies that consider the specificities of the research context (Massaro et al. 2015, 2016a). For example, the public sector cannot simply translate models developed for the private sector. Similarly, SMEs cannot simply translate the models used in large companies.

Furthermore, specialization is considered a normative decision response to high complexity, uncertainty and the accelerated pace of change in today's world. These characteristics are brought about by mega trends of globalization, virtualization and knowledge centricity. By focusing on specific aspects of a problem rather than all of it at once, individuals and collectives may better deal with the challenges they face. The same principle applied to $\mathrm{KM}$ resulted in several emerging specializations. The most popular ones 
are: big data and its related concepts of business intelligence and business analytics, social knowledge and innovation management.

Big data, business intelligence and business analytics (BI/BA) can be viewed as an adaptation of the codification KM strategy aimed at knowledge preservation and discovery. Capturing explicit knowledge is essential for the purpose of minimising the risk of knowledge loss (Von Krogh et al., 2000), while discovering and making visible novel patterns hidden in knowledge stores is important for better knowledge access, discussion and value (Eppler \& Burkhard, 2007). The roots of the big data and business intelligence approaches can be found in structured database and data warehousing systems, as well as in unstructured web-based and mobile content. These vast digital collections offer plenty of opportunities for analytical activities to drive decisions and actions. Typically, analytical techniques are classified according to their purpose into: descriptive (aimed at revealing patterns), predictive (used in forecasting future) and prescriptive (for recommending an optimum course of action) (Edwards \& Taborda, 2016).

Another emerging KM specialization is labelled social knowledge management and is placed as part of social business, an umbrella term for the use of social tools within an organization (Gurteen, 2012). This powerful approach clearly puts responsibility for knowledge sharing, and making it productive, in the hands of people. In the world of social KM, a powerful combination of soft (e.g. knowledge café) and technological social tools (e.g. blog) facilitates knowledge sharing, collaboration, connectedness and relationships that are leveraged towards business objectives. The term social KM, may also be understood as the management of social knowledge that addresses developmental objectives of regions or the entire global community, beyond one organization's competitive advantage.

Some authors claim that innovation is the most important driver of $\mathrm{KM}$, as innovation ensures advancement rather than just survival in the knowledge economy (Von Krogh et al., 2000). It is therefore not surprising that innovation management emerged as an important trend in business research and practice. For innovation to happen, visionary ideas and creative leaps need to be turned into disruptive realities. The story of the people who created the digital revolution is a useful account of how inventors' minds worked and what made them so inventive. It is also a narrative of how their collaboration and teamwork made them even more creative (Isaacson, 2014). For an era that seeks to foster creativity and innovation, this KM specialization may perhaps be the right way forward.

Overall, with specialization, different notions of KM have come along and are gaining popularity. Davenport (2015) urges the KM community not to shun, but instead embrace these other related notions and thus allow the idea of KM to thrive. 


\section{Reconceptualization}

One of the strangest "back to the future" kinds of theoretical developments mentioned in the recent literature is the re-emergence of the concept of data science. According to Hayashi (1998), data science is a concept that unifies statistics, data analysis and their related methods in order to understand and analyse actual phenomena with data. It employs processes and systems from the areas of mathematics, statistics and computer science to extract insights from data. Based on this definition, it is not possible to see any distinction between data science and the KM concept of knowledge discovery as described by Fayyad et al. (1996). Some critics consider data science as a buzzword that simply replaced business analytics, which replaced data mining as the term of choice for describing the analysis of data (Press, 2013). Therefore, the rise of data science may signal the beginning of the decline of the business analytics.

A very different theoretical lens on $\mathrm{KM}$ is provided by connectivism (Siemens, 2005). It is inspired by the era of networks and collaboration, and addresses the gap between the existing KM theories and emerging knowledge initiatives such as Web 2.0. Connectivism contrasts traditional behavioral and cognitive approaches to learning by acknowledging the role of social and cultural context of learning. It is often promoted as a learning theory for the digital age. Siemens also opened a discussion on the notion of collectivism versus connectivism. He argued in favour of connective intelligence as it permits retaining own ideas in collaboration with others, and against collective intelligence which overwrites individual identity.

Among the recommendations for KM's future, experts from Heisig's (2015) study mentioned: revisiting some fundamentals such as the concepts of knowledge and the KM process; and exploration of ecological and biological models of the KM environment. The search for the evidence of such explorations led to the concept of nature knowledge (NK), nature knowledge theory (NKT) and its derivative human system biology-based knowledge management (HSBKM) model (Santo, 2015). NKT has been developed based on the postulate that nature knowledge is the source and centre of consciousness and that human knowledge is essentially part of a nature knowledge continuum. Generated from NKT, the HSBKM model defines KM as the act of managing either personal or organizational consciousness as the attribute of knowledge. Such redefining of knowledge and KM, in the upstream science way, gives it an incredibly broad cosmic meaning.

In the end, one can be certain that whatever path KM may take in the future, it will live as long as there are people interested. 


\section{CONCLUSION}

This paper portrays KM as a dynamic and constantly changing field. With respect to the KM past, the paper reveals that the infancy of the field was plagued by fragmentation. This was followed by a more mature stage characterised by a comprehensive integration of separate approaches into proactive practices. Beyond this, there was a notable tendency discovered towards the fusion of KM with other disciplines, with less emphasis on doing $\mathrm{KM}$ and more on exploiting KM for various business reasons.

However, exactly where the field will be moving from here is open for debate. While it is clear that KM is neither dead nor short of breath (based on the amount and diversity of research in the field being undertaken), it may be wise to be cautious about making concrete predictions as to what direction it will take in the future. This paper attempted to shed some light on the possible directions of the field by identifying extension, specialization and reconceptualization as three visible emerging trends. It is also possible that something else is going on, but remains undetected to date.

These findings have important implications for $\mathrm{KM}$ research and practice. For research, they show that the landscape of KM is quite varied and suggest that those who believe in KM should embrace these different notions under the "KM Conceptual Umbrella". The umbrella metaphor assumes that within its boundaries many themes, ideas, approaches and tools concerning knowledge can be addressed. Thus, KM may be in the vanguard of development at personal to global levels. These findings also warn KM practice of the danger that the field may completely disappear and organizations may forget what they knew about KM and fail to manage their knowledge for the benefit of their business. Contrary to some opinions that KM's disappearance would indicate its true success this paper recommends that the next KM generation should make sure that KM remains relevant.

Irrespective of whether KM regeneration or revolution will be the more likely scenario, it seems that interesting times lie ahead. However, such conclusions need to be interpreted with caution due to the current methodological limitations. The traditional literature review applied in this study has been criticized in recent literature because of a lack of rigour (Massaro et al. 2016b). Therefore, using a more rigorous structured literature review (SLR) is recommended as a way of potentially developing more robust and defensible future research agendas and questions. 


\section{REFERENCES}

AS 5037 (2003). Interim Australian Standard: Knowledge Management. Sydney: Standards Australia International.

Becerra-Fernandez, I., Gonzales, A., \& Sabherwal, R. (2004). Knowledge Management: Challenges, Solutions, and Technologies. Upper Saddle River, New Jersey: Pearson Education Inc.

Becerra-Fernandez, I., \& Sabherwal, R. (2001). Organizational knowledge management: A contingency perspective. Journal of Management Information Systems, 18(1), 23-55.

Bedford, D.A., \& Lewis, J. (2015). Introduction to the special issue: Knowledge management models and theories. Journal of Information and Knowledge Management, 14(4), 1-4.

Bolisani, E., \& Handzic, M. (Eds.) (2015). Advances in Knowledge Management: Celebrating 20 Years of Research and Practice. Knowledge Management and Organizational Learning Series,1, Switzerland: Springer International Publishing.

Cervone, F. (2016). What might the curriculum in knowledge management programs tell us about the future of the field? Proceedings of the 17th European Conference on Knowledge Management. Belfast (UK), 1-2 September.

Cope R.F.III, Cope, R.F., \& Hotard, D.G. (2006). Enhancing project management with knowledge Management principles. Allied Academies International Conference 2006, New Orleans, LA.

Cummings, S., Regeer, B.J., Ho, W.W.S., \& Zweekhorst, M.B.M. (2013). Proposing a fifth generation of knowledge management for development: Investigating convergence between knowledge management for development and transdisciplinary research. Knowledge Management for Development Journal, 9(2),10-36.

Davenport, T. H. (2015). Whatever happened to knowledge management? The Wall Street Journal, June 24, Retrieved April 27, 2017 from http:// www.tomdavenport.com/wp-content/uploads/Whatever-Happenedto-Knowledge-Management.pdf

Dixon, $N$ (2010). The three eras of knowledge management - summary. Retrieved April 27, 2017 from http://www.nancydixonblog.com/2010/08/ the-three-eras-of-knowledge-management-summary.html

Earl, M. (2001). Knowledge management strategies: Toward a taxonomy. Journal of Management Information Systems, 18(1), 215-233.

Edwards, J., Handzic, M., Carlsson, S., \& Nissen, M. (2003). Knowledge management research and practice: Visions and directions. Knowledge Management Research and Practice, 1(1), 49-60.

Edwards, J. S., \& Taborda, E. R. (2016). Using knowledge management to give context to analytics and big data and reduce strategic risk. Procedia Computer Science, 99, 36-49. 
Eppler, M.J., \& Burkhard, R.A. (2007). Visual representations in knowledge management: Framework and cases. Journal of Knowledge Management, 11(4), 112-122.

Favero, J.C.T. (2016). The disruptive future of knowledge management. Retrieved April 24, 2017 from http://www.kminstitute.org/blog/ disruptive-future-knowledge-management

Fayyad, U., Piatetsky-Shapiro, G., \& Smyth, P. (1996). The KDD process for extracting useful knowledge from volumes of data. Communications of the ACM, 39(11), 27-34.

Garlatti, A., \& Massaro, M. (2015). Is KM declining? Electronic Journal of Knowledge Management, 14(1), 1-4.

Girard, J., \& Ribiere, V. (2016). Mapping the future of KM through Earl's KM Taxonomy Lens. Online Journal of Applied Knowledge Management, 4(1), 180-191.

Gudi, A., \& Becerra-Fernandez, I. (2006). Role of knowledge management in project management of complex systems organizations. NASA Knowledge Management and Successful Mission Operations Conference 2006, Houston, TX.

Gurteen, D. Ed. (2012). Leading Issues in Social Knowledge Management. Reading, UK. Academic Publishing International Ltd.

Hahn, J., \& Subramani, M.R. (2000). A framework of knowledge management systems: Issues and challenges for theory and practice. In Proceedings of the International Conference on Information Systems, ICIS'2000, Brisbane, Australia, 302-312.

Handzic, M., \& Durmic, N. (2015). Knowledge management, intellectual capital and project management: Connecting the dots. Electronic Journal of Knowledge Management, 13(1), 51-61.

Handzic, M., Lagumdzija, A., \& Celjo, A. (2008). Auditing knowledge management practices: Model and application. Knowledge Management Research \& Practice, 6(1), 90-99.

Handzic M. (2015). A descriptive analysis of knowledge management research: Period from 1997 to 2012. In E. Bolisani \& M. Handzic (Eds.), Advances in Knowledge Management: Celebrating 20 years of research and practice (pp. 45-64). Switzerland: Springer International Publishing.

Handzic, M. (2016). Knowledge management evolution: Reflections on past and predictions for future. In Proceedings of the 8th International Conference on Innovation and Knowledge Management in Asia Pacific (IKMAP 2016), 23-24 October, Kobe, Japan, 73-82.

Hansen, M. T, Nohria, N., \& Tierney, T. (1999). What's your strategy for managing knowledge? Harvard Business Review, March-April, 106-116.

Hasan, H., \& Handzic M. Eds (2003). Australian Studies in Knowledge Management, Wollongong, Australia: University of Wollongong Press.

Hayashi, C. (1998). What is data science? Fundamental concepts and heuristic example. In Studies in Classification, Data Analysis, and Knowledge Organization (pp. 40-51), Japan: Springer. 
Heisig, P. (2015). Future research in knowledge management: Results from the global knowledge research network study. In E. Bolisani \& M. Handzic (Eds.), Advances in Knowledge Management: Celebrating 20 years of research and practice (pp. 151-182). Switzerland: Springer International Publishing.

Isaacson, W. (2014). The Innovators: How a Group of Hackers, Geniuses, and Geeks Created the Digital Revolution. New York, USA: Simon \& Schuster. Ismail, W.K.W., Nor, K.M., \& Marjani, T. (2009). The role of knowledge sharing practice in enhancing project success. Institute of Interdisciplinary Business Research, 1.

Kay, A.S. (2003). The curious success of knowledge management. In C.W. Holsapple (Ed,), Handbook on Knowledge Management 2: Knowledge Directions (pp. 679-687), Berlin-Heidelberg: Springer-Verlag.

Kianto, A., Ritala, P., Spender, J. C., \& Vanhala, M. (2014). The interaction of intellectual capital assets and knowledge management practices in organizational value creation. Journal of Intellectual Capital, 15(3), 362 $-375$.

Lelic, S. (2002). Karl Wiig. Knowledge Management, 6(2), 7-9. Retrieved April 24, 2017 from http://www.krii.com/downloads/wiig_km_interview.pdf

Levin, G. (2010). Knowledge management success equals project management success. PMI Global Congress, 11 Oct 2010, Washington D.C.

Lierni, P.C., \& Ribiere, V.M. (2008). The relationship between improving the management of projects and the use of KM. The Journal of Information and Knowledge Management Systems, 38(1), 133-146.

Massaro, M., Dumay, J., \& Garlatti, A. (2015). Public sector knowledge management: A structured literature review. Journal of Knowledge Management, 19(3), 530-558.

Massaro, M., Handley, K., Bagnoli, C., \& Dumay, J. (2016a). Knowledge Management in Small and Medium Enterprises. A structured literature review. Journal of Knowledge Management, 20(2), 258-291.

Massaro, M., Dumay, J.C., \& Guthrie, J. (2016b). On the shoulders of giants: Undertaking a structured literature review in accounting, Accounting, Auditing and Accountability Journal, 29(5), 767-901.

McQuary, J., \& Hester, J. (2011). The Future of Knowledge Management: A Vision For 2020. Retrieved April 27, 2017 from https://www.apqc.org/ sites/default/files/files/Hester,\%20Jeff\%20\&\%20McQuary,\%20John\%20 -\%20Fluor.pdf

Molodchik, M. A., Shakina, E. A., \& Barajas, A. (2014). Metrics for the elements of intellectual capital in an economy driven by knowledge. Journal of Intellectual Capital, 15(2), 206-226.

Nonaka, I., \& Konno, N. (1998). The concept of ba: Building a foundation for knowledge creation. California Management Review, 40(3), 40-54.

O'Leary, D.E. (2016). Is knowledge management dead (or dying)? Journal of Decision Systems, 25(S1), 512-526. 
Owen, J. (2008). Integrating knowledge management with programme management. In Current Issues in Knowledge Management (pp.132148). New York: IGI Global.

Press, G. (2013). Data science: What's the half-life of a buzzword. Forbes, 19 ${ }^{\text {th }}$ August. Retrieved May 10, 2017 from https://www.forbes.com/ sites/gilpress/2013/08/19/data-science-whats-the-half-life-of-abuzzword/\#1e0ec8627bfd

Santo, M. (2015). Redefining Knowledge and Knowledge Management the Upstream Science way. Retrieved May 10, 2017 from http://www. km4dev.org/forum/topics/redefining-knowledge-and-knowledgemanagement-the-upstream

Schlussel, A. (2009). What is knowledge management? And why we should care. Retrieved April 24, 2017 from https://www.slideshare.net/ artschlussel/what-is-knowledge-management-2979169

Schmitt, U. (2015). Quo Vadis, knowledge management: A regeneration or a revolution in the making? Journal of Information and Knowledge Management, 14(4). Retrieved from http://dx.doi.org/10.1142/ S0219649215500306

Serenko, A., \& Dumay, J. (2015a). Citation classics published in knowledge management journals. Part I: articles and their characteristics. Journal of Knowledge Management, 19(2), 401-431.

Serenko, A., \& Dumay, J. (2015b). Citation classics published in knowledge management journals. Part II: studying research trends and discovering the Google Scholar Effect. Journal of Knowledge Management, 19(6), 1335-1355.

Serrat, O. (2017). How would you motivate interest in knowledge management? Retrieved from DOI: 10.13140/RG.2.2.16865.10081

Siemens, G. (2005). Connectivism: A learning theory for the digital age. International Journal of Instructional Technology and Distance Learning, 2(1), Article 1. Retrieved May 10, 2017 from http:// er.dut.ac.za/bitstream/handle/123456789/69/Siemens_2005_ Connectivism_A_learning_theory_for_the_digital_age.pdf

Skyrme, D. (2013) The Seven Ages of Information \& Knowledge Management: What Have We (Not) Learned? Retrieved April 27, 2017 from https:// www.skyrme.com/kmarticles/7ikm.pdf

Snowden, D. (2002). Complex acts of knowing: Paradox and descriptive selfawareness. Journal of Knowledge Management, 6(2), 110-111.

Spender, J.C. (2015). Knowledge management: Origins, history, and development. In E. Bolisani \& M. Handzic (Eds.), Advances in knowledge management: Celebrating 20 years of research and practice (pp. 3-23). Switzerland: Springer International Publishing.

Sveiby, K. (1997). The New Organizational Wealth. San Francisco: BerretKoehler.

Ternai, K., Torok, M., \& Varga, K. (2014). Combining knowledge management and business process management - a solution for information extraction 
from business process models focusing on BPM challenges. In A. Ko \& E. Francesconi (Eds.), Electronic Government and the Information Systems Perspective, Lecture Notes in Computer Science, 8650. Cham: Springer. Tuomi, I. (2002). The future of knowledge management. Lifelong Learning in Europe, 7(2), 69-79.

Von Krogh, G., Ichijo, K., \& Nonaka, I. (2000). Enabling Knowledge Creation. New York: Oxford University Press Inc.

Wu, Y., Zhong, J.J., \& Sun C.X. (2007). The fusion model of knowledge management and communication management. Research Organization, International Conference on Wireless Communications, Networking and Mobile Computing (WiCom 2007).

Yeong, A., \& Lim, T.T. (2010). Integrating knowledge management with project management for project success. Journal of Project, Program \& Portfolio Management. 1(2), 8-19.

\begin{abstract}
Polish)
W niniejszym artykule prześledzono zmiany $w$ dziedzinie zarzq̨dzania wiedzq (ZW) na przestrzeni lat w oparciu o przeglad literatury i własne badania autorki. Artykuł zaczyna się od powrotu do poczq̨tków ZW i odzwierciedla trzy istotne etapy ewolucyjne, nazywane fragmentacjq, integracjq i fuzjq. Po tych refleksjach nad przeszłościq ZW, artykuł spekuluje o możliwych ścieżkach przyszłości ZW. Określa on trzy pojawiajqce się tendencje zwane rozszerzeniem, specjalizacjq i rekonstrukcjq, które wskazujq na kilka możliwych przyszłych scenariuszy rozwoju ZW. Pierwsze dwa dotyczq decentralizacji i regeneracji wcześniejszych interpretacji $Z W$, a trzecia tendencja wskazuje na następnq rewolucyjnq fazę ZW. Niezależnie od kierunku, jakim może podążyć ZW, dowody przedstawione $w$ niniejszym artykule sugeruja, że ZW ma przyszłość, chociaż nie jest ona pozbawiona wyzwań.
\end{abstract}

Słowa kluczowe: zarzq̨dzanie wiedzq̨; ZW; Rozwój ZW; ZW w przeszłości; ZW w przyszłości.

\title{
Biographical note
}

Meliha Handzic is a Full Professor at the International Burch University, Sarajevo, Bosnia and Herzegovina. She gained her Ph.D. in Information Systems from the University of New South Wales, Sydney, Australia. Her main research interests lie in the field of knowledge management (KM) with a particular focus on the processes and socio-technological enablers of knowledge development and transfer. She has published widely on these topics in books, journals and conference proceedings. Meliha is also an active member of IAKM, Regional editor of KMRP and serves on editorial boards, executive and program committees for numerous international and national journals and conferences. 
